Protist vol 170

https://doi.org/10.1016/j.protis.2019.07.002

FROM THE ARCHIVES

Unmasking "The Eldest Son of the Father of Protozoology":

Charles King

John R. Dolan ${ }^{1}$

Sorbonne Université, CNRS, Laboratoire d'Océanographie de Villefranche-surMer, Station Zoologique, BP 28, France

In 1703 two articles appeared in the Transactions of the Royal Society, authored by an unnamed gentleman. The articles, with deference to Leeuwenhoeck, described recent observations made with a microscope. Clifford Dobell, in his biography of Leeuwenhoeck, remarked at length on the extraordinary quality of the illustrations and descriptions of "animalcules". He declared the anonymous author to be the scion and master draughtsman of Leeuwenhoeck's followers. Still today, one of the illustrations is credited with being the first unambiguous depiction of a diatom. Here I present evidence that the anonymous author was Charles King of Staffordshire and evidence of his talent. John Hill is often credited for the first naming and illustrating Paramecium and other ciliates in his 1752 book, but it has been claimed repeatedly that he copied the anonymous 1703 illustrations without attribution. Here, the illustrations from 1703 and 1752 are given, and casual examination suffices to show not only that the illustrations were copied, but also that the 1703 illustrations (and text descriptions) of Charles King are of a far higher quality than those of John Hill. Although very little is known about Charles King, he deserves recognition as a pioneer of protistology.

1dolan@obs-vlfr.fr

Running Head: Unmasking Charles King

Key words: Euplotes; History of Science; microscopy; Paramecium; plagiarism; Tabellaria 


\section{Introduction and Backstory}

By way of introduction, I wish to begin by explaining why a mystery over 300 years old became of interest to me and how it was unexpectedly solved. The story begins with a vain search for possible descriptions of tintinnid ciliates antedating Müller's first brief description (Müller, 1776). Concerning works before Müller, Dujardin, in a "discours préliminaire", (Dujardin, 1841), remarked that Hill (Hill, 1752a) was the first to give scientific names to "animalcules". He then went on to say that Bruguières's catalogue of infusoria (Bruguières, 1791) was mostly a copy of Müller but with minor additions of a few species of Baker's (Baker, 1742) - species that apparently would not have been in Müller (Müller, 1776). These remarks led me to review Bruguières, Hill, and Baker in the hope of finding an early description of one or more tintinnids. Alas, no tintinnids were apparent anywhere. What I did find was that Baker and Hill did describe animalcules, but Baker's were rotifers and Hill's were mostly Paramecia.

Intrigued by these early works, I investigated the relevance of Hill's early ciliate descriptions by searching for citations to 'J. Hill 1752a'. This revealed both credits to, and pointed criticisms of, John Hill. Remarkably, Corliss listed John Hill very prominently among "Outstanding Earliest Protozoologists" between Leeuwenhoeck and Müller, devoting to Hill about the same amount of text given to the other two undisputed pioneers of protistology (Corliss, 1978). In contrast, Cole's "The History of Protozoology" (Cole, 1926) contained no mention at all of Hill. Similarly, Saville Kent (1880-1881) in his chapter on "General History of the Infusoria" makes no mention of Hill. In discussions of protist taxonomy, Hill is often credited with being the first to give scientific names to ciliates, i.e., Paramecium and Cyclidium, (e.g. Aescht, 2001, Fokin, 2004, Lahr et al, 2012; Ratcliff, 2009), and is mentioned in some summary histories of protozoology (e.g. Kudo, 1954). However, controversially, Hill's work has been criticized for containing illustrations copied without attribution. The first to notice this shortcoming was apparently O.F. Müller (Müller, 1786) who noted that Hill's drawings of Paramecia appeared to be unattributed copies (Ratcliff, 2009). Woodruff was more specific (Woodruff (1926) saying Hill had copied some of the figures of protozoa in Hill 1752a from "antiquated Philosophical 
Transactions of the Royal Society". Dobell, in his biography of Leeuwenhoeck (Dobell, 1932), was quite specific, naming the source of Hill's illustrations of 'animalcules' in his 1752 book "An History of Animals" as from an anonymous 1703 article, an article comprising an extract of letters from an anonymous "Gentleman in the Country". Dobell pointed out that it was ironic that Hill in 1752a copied from the Philosophical Transactions just after publishing a lengthy criticism of the journal (Hill, 1751). Hill's critique of the Philosophical Transactions included sharp words on Leeuwenhoeck, which no doubt did little to endear Hill to Dobell:

\footnotetext{
"We are to acknoweldge that Merit, great Merit indeed, in Lewenhoeck; he had the good fortune to be one of the first people who worked at microscopical observations, but we are to acknowledge at the same Time, that he has the Honour of having stocked the Philosophical Transactions with more Errors than any one Member of it, excepting only his Successor in Peeping, Mr. Baker*" (Hill, 1751 pg. 156)

*Henry Baker, author of "The Microscope Made Easy" (Baker, 1742) and frequent Council Member of the Royal Society (Turner, 1974).
}

With regard to the 1703a paper, Dobell commented at length on the quality of the illustrations and attractive simplicity of the text. Dobell pointed out that another article by the same hand contained an illustration of what was indisputably the diatom Tabellaria (Anon. 1703b). These latter illustrations have been described as the first certain record of a diatom, but missing unfortunately, the identity of the author (Mann, 2002, Mann, 2010, Manton, 1983, Round et al., 1990). The depiction is apparently not well-known as others, for example Müller, are credited instead for being the first to illustrate a diatom (e.g., Manton, 1983). The same plate also appears to include the first depiction of copepods clearly distinguishable as calanoid and harpacticoid copepods (Damkaer, 2002). Dobell described the anonymous author and illustrator as the first follower of Leeuwenhoeck and therefore "the eldest son of the father of protozoology". In a footnote, Dobell states 
"The letters themselves are not in the Society archives or the British Museum (so far as I have been able to ascertain), and all documents relating to them appear to have been destroyed. In view of their great interest, I have made repeated attempts to discover their authorship; but every clue has proved unavailing, and I fear that "The Gentleman in the Country" covered up his tracks on purpose- in order to remain anonymous for ever" (Dobell, 1932, pg. 371).

Dobell's text then sent me to examine the 1703 articles in question. I found the plates to be, as Dobell said, extraordinary for the time, and the descriptions charming. The articles are provided in the Supplementary Materials.

Searching for documents containing the title of the first article, unexpectedly solved the mystery of the identity of the author. While evidence relating to the articles may have been destroyed when Dobell was writing in 1932, some evidence apparently existed in 1887. A "Quaeritur" letter was published in Nature entitled "Who was Charles King?" It was a plea for information on a "Mr. Charles King of Staffords.". The letter states that, according to contemporary notes on a copy of the 1703 articles, the author is identified as one "Mr. Charles King, student of Ch. Ch. Oxon." (Ch Ch Oxon = Christ Church Oxford), and in the margin also notes "Walter Chetw. of Ingestry Staffords." The Quaeritur letter writer states that "...we have some early and first-rate contributions to microscopical science...". Ironically the plea is signed only "S, The Hague", so the anonymous author of 1703 was revealed by another anonymous author asking for information! I was unable to find any evidence of who was "S" in the Hague in 1932.

Simply searching for "Charles King Staffordshire" using Google revealed who was this Charles King. It brings up a passage in a 1686 book by Robert Plot, "The Natural History of Stafford-Shire" (Plot, 1686). On page 224 Plot writes

".... An. 1680 by that curious observer Walter Chetwynd Esq.; now high-sherriff of the county and his ingenious Chaplain Mr. Charles King Student of Ch. Ch. who by the help of a Microscope observed several 
minute eggs in a small oak ball taken from the ribbe on the back side of an oak-leaf gather'd in the field below Ingestre house....". (pg 224 in Plot , 1686)

Thus was found the early microscopist "Charles King, Staffords.", with unexpected ease and with close links to the Royal Society. Both Robert Plot, an Oxford don, and Walter Chetwynd, a wealthy member of parliament, were members of the Royal Society at that time and were well acquainted with one another (Chatters, 2017). Charles King, in his only signed communication to the Royal Society (a short letter on crayfish molting), states that Dr. Plot showed him a book, Sach's Gammarologia (King, 1701). Thus, he appears to have been in close communication with Robert Plot. Robert Plot was an important figure in the Royal Society acting as Secretary and an Editor of the Transactions from 1682-1684 (Turner, 2004). Charles King also helped Walter Chetwynd with his ultimately unfinished project of writing a history of Staffordshire by aiding with illustrations of coats of arms (Greenslade, 2004). It is likely safe to assume that Walter Chetwynd and Charles King were close collaborators. In 1693 Walter Chetwynd died of smallpox and bequeathed to his Chaplain Charles King the considerable income of 40 pounds a year (Wedgwood, 1920). I speculate that Charles King, 10 years later, wished to remain anonymous in his communications to the Royal Society in order to avoid any fame that might overshadow his former employer and lifetime benefactor.

Do we know any more of Charles King? Judith Curthoys, the Archivist at Christ Church Oxford, kindly provided the following information on the Charles King who attended Christ Church Oxford from 1671 to 1678, presumably our man. Charles King was born in Hadham in Hertfordshire in 1654, the son of John King, a gentleman. He matriculated on 15 July 1671, aged 17. He first attended as a commoner (that is, an ordinary fee-paying undergraduate) but was soon elected to a Studentship, similar to a scholarship today, on the nomination of Dean John Fell. Charles King held a Morris Exhibition which was designed to encourage the study of Oriental (Biblical) languages. He received his BA in 1675 and his MA in 1678. In 1682 he was approved as a tutor which enabled him to take his own pupils. In 1694, he was appointed catechist, with the task of 
ensuring that the undergraduates were properly versed in Anglican doctrine. In 1697, he was appointed vicar of Deddington in Oxfordshire. Thus, Charles King appears to have been a gentleman from the country who was also a remarkable scholar, educator, and a vicar.

\section{Observations of a Gentleman from the Country}

The first 1703 communication to the Royal Society, titled "An extract of some letters sent to Sir C.H. relating to some microscopical observations" is dated Aug. 11 1702. Figure 1 given here is the plate illustrating this first article of 1703 (Anon., 1703a). He described bristles on the body of a mite (Fig. A.). He then goes on to describe the proboscis of a tick he pulled off his arm (Fig. B), and then he compares it to the proboscis of a dog tick (Figs $\mathrm{Ba}, \mathrm{Bb}$ ). Figure $\mathrm{C}$ shows organisms which appeared in an infusion of peppercorns after 3 or 4 days, 'slender long worms all of the same thickness but of various lengths'. He estimated their thickness to be less than 1/100 of hair's breadth and called them 'Capillary Eels'. Saville Kent (1880-1881) described these observations "... as a remarkably clear and graphic account of several species of the exceedingly minute and low-organized Phytozoa, Vibrio and Spirillum...". Figure D shows sperm cells from the testicles of a buck.

Returning to observations of 'Animalcules in Waters'. He states that many of the same forms appear in different infusions and in a consistent order. He speculates that they are the 'spawn of some invisible Volatile Parents'. His observations of successional patterns in microbial communities were likely the first and his observation also hints at the genesis of germ theory. Figure E shows an organism which he called very common in his infusions. He observed it to extend, contract, and coils its 'Tayl'. The body is said to be about $1 / 3$ of a hairbreadth in diameter. The description of Figure F, which appears to be Paramecium, is transcribed below to permit appreciation of his text.

"Those Animalculi marked $\boldsymbol{F}$. are also plentiful in all the Waters and are the largest of all, and I can see them in a good light and position (without any other assistance) with my bare Eye. Their length being 
about the breadth of a Hair. These have a very quick motion, and are perpetually beating about like a Spaniel in a Field, and by their frequent turns and returns, sudden stops, and casting off, seem to be always Hunting for Prey. Their Bodies are very thin, that which I take to be the Back being much darker than the other side, and you shall see them frequently turn sometimes one side and sometimes the other toward your Eye, and many times you may see part of each. Their edges are as it were fringed with a multitude of very minute Feet, which are most conspicuous about the Head and hinder parts, where are also some Bristles longer than the Feet, which shew like a Tayl, $\boldsymbol{a}$ shews one of these with the Back, and $\boldsymbol{b}$ one with the Belly toward you, and in $\boldsymbol{c}$ and $\boldsymbol{d}$ I have endeavoured to represent it as it often appears other postures. I put some short shreds of my Hair into their Water to compare their magnitudes by, and saw that they could use their Feet in Running as well as Swimming, for they would often stand on an Hair, and go on it forward and backward from end to end, often stooping down and bending themselves in several postures. " (Anon.,1703a, p 1368)

Figure G shows organisms, which from the text description of size, and their behaviour, were likely Euplotes ciliates (see supplemental file 1 Anon., 1703a, pp 13-14). Figure H depicts organisms found in standing water drained from a horse dunghill, one of the sorts of organisms he had not previously seen. They are described, without information as to size, having bright extremities, the middle dark and covered with bristles and having a pointed tail with a "spring on its end". Figure K shows another sort of "Capillary Eels" from the same dung heap water kept for several days. He states that the number of Eels decreased every day and the forms shown Fig. L increased in number, described as rotating swimming sacs, always keeping the pointed end forward. Another sort found, which extends into a cylindrical form and retracts into a globular form, shown in Fig. $\mathrm{M}$ is possibly some sort of vorticellid. The final figure, $\mathrm{N}$ depicts an organism described as about the size of the organism in Fig. M and being nimble in motion always keeping the sharp end forward. It is variable in color with some being 
transparent, other curiously striated from the point to the thick end, some with the fore part clear, the rest dark.

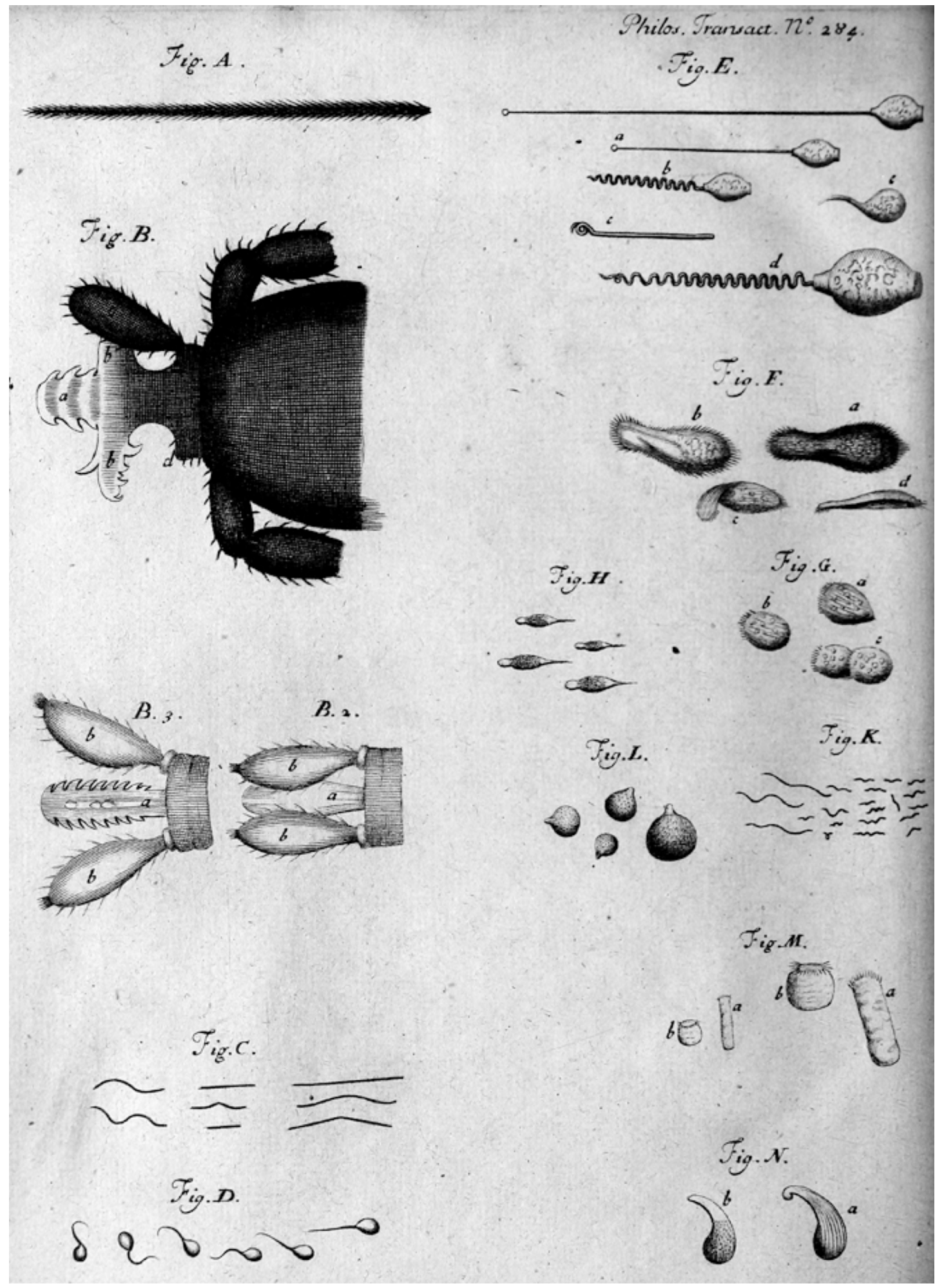

Figure 1. Plate from the first anonymous communication "An extract of some letters sent to Sir C.H. relating to some microscopical observations" (Anon. 1703a) 
Saville Kent in his chapter "General History of the Infusoria from the time of their discovery by Leeuwenhoek in 1675 to the year 1880" praised the anonymous writer and gave him credit for providing the first clearly identifiable illustrations of Paramecium, Vorticella, Euplotes, Enchelys, and Oxytrichia and bacteria as noted above (Saville Kent 1880-1881). Francis J. Cole, in his 'History of Protozoology' (Cole, 1926) described the first 1703 communication as "an important communication by an anonymous writer". He gives the writer credit not only for the first descriptions and figures of protists, he also gives the writer credit for the first observation of division, though incorrectly interpreted as conjugation.

The second 1703 communication is titled "Two Letters from a Gentlemen in the Country, relating to Mr. Leuwenhoeck's letter in Transaction, no. 283" (given in the supplementary files as Anon. 1703b). The title refers to Leeuwenhoeck's letter describing 'animalcules' associated with the roots of a pondweed (Leeuwenhoeck 1703). Leeuwenhoeck's depiction of a variety of organisms attached to the roots (see the supplementary file Leeuwenhoeck 1703) has been claimed by some to include epiphytic diatoms but the figure does not clearly show any diatoms (De Wolf 1993). This is in contrast to the figures in the plate accompanying the text of "a Gentleman from the Country", given here as Figure 2. It can be seen from the plate that this latter article largely concerned observations on metazoan organisms now known as Hydra and copepods. This article contains not only the first depiction of calanoid and harpacticoid copepods (Damkaer 2002) but also the first unambiguous, indeed detailed, illustration of a diatom (Mann 2002, 2010, Manton 1983, Round et al. 2009) in the figures VII and VIII. Below is a transcript of the observations made, concluding with the astute opinion that they are microscopic plants.

"In my observation of these Stalks*, I often saw adhering to them (and sometimes separate in the Water) many pretty branches, compos'd of rectangular oblongs and exact squares, which were joined together as you may see in Fig. VII which I drew as exactly as I could from one of them. There are often twenty or more of these Figures in one branch, which generally adheres at one end to the Stalks of the Plant, and I 
think it remarkable that these rectangular parallelograms are all of the same size, the longest side not exceeds $1 / 3$ of an hairs breadth, and that the length is just double the breadth, the squares being visibly made up of two parallelograms joyn'd longwise. They seem very thin, and the texture of every one is nearly the same. To a very large Magnifier they appear as in Fig. Vlll. I took these branches at first for Salts, but finding them always of the same size, and that there was no sensible encrease of their bulk while they continued in the Water, that after they had lain a day or two dry on a Glass Plate they altered not their Figure, and upon the addition of new Water (warm or cold) they had still the same appearance and cohesion, and that their adherence (tho touching only in the angular points) was so firm and rigid, that all mov'd together, and kept the same position in respect of one another , however, agitated by the Water; these considerations, I say, perswade me, that they may be rather Plants than Salts, but they being so verv minute that no judgment can be made of'em but by the Eye, I shall not determine any thing positively. " (Anon., 1703b, p 1499)

*of the pond weed, Lemna 


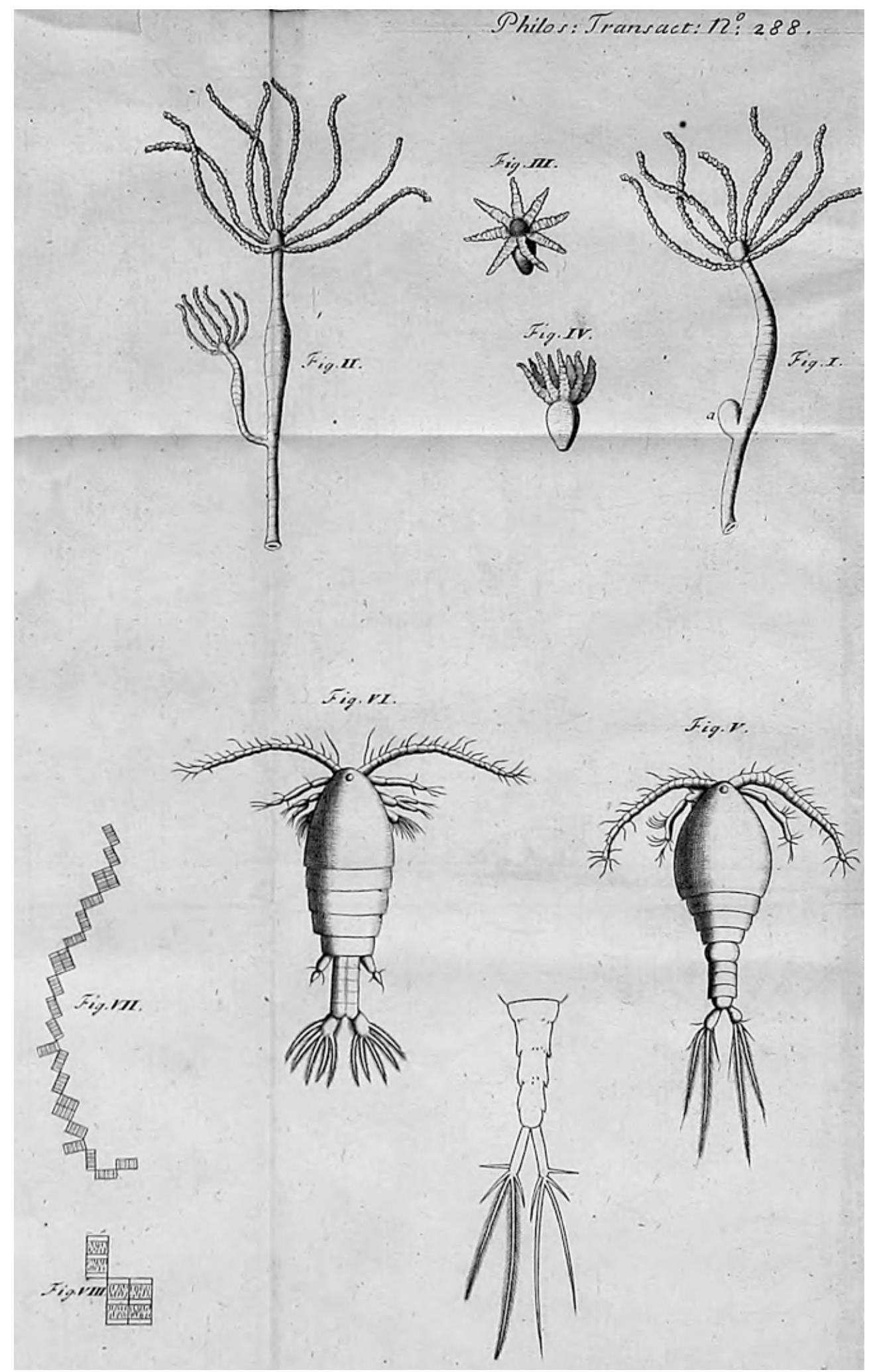

Figure 2. Plate from the second anonymous communication "Two Letters from a Gentlemen in the Country, relating to Mr. Leuwenhoeck's letter in Transaction, no. 283" (Anon. 1703b). Note the figures VII and VIII clearly showing the diatom Tabellaria. 


\section{John Hill's 1752 Illustrations}

The novelty and accuracy of the observations of the "Gentleman from the Country", perhaps first noted by Saville Kent (1880 1881) and then by Cole (1926), were amply remarked upon by Dobell (1932) and have been shown here. The evidence presented in the Introduction supports the hypothesis that the author was Charles King of Staffordshire, an early adept of the microscope. The matter remaining is the claim of Woodruff (1926) and Dobell (1932) that the images identified here as those of Charles King were copied in the depictions of John Hill published in 1752a. Hill in the preface to "An History of Animals" volume claims to have observed himself all the organisms depicted.

"I have been at the pains of viewing all these by the microscope, and not according to the erroneous accounts of those superficial writers, who have treated of some of them, or of those who only pretend to have seen others', but, from what appeared on that examination" (Hill 1752a, p 3)

There is actually surprisingly little evidence of Hill having much experience observing microscopic organisms. A bibliography of Hill's works appears in Rousseau (2012). Hill's writings concerning microscopic organisms appear to consist uniquely of a few brief descriptions found in his 1752 "Essays" which contains no illustrations (Hill, 1752b).

Below is the plate in Hill's 1752 An History of Animals, Plate 1., depicting "animalcules". The insets show illustrations from the first 1703 communication (Anon., 1703a). Some of the insets are shown reversed (i.e., Paramecia \& Craspedaria) to conform to the orientation in the plate from Hill (1752a). There would appear to be little doubt that Hill copied the illustrations, or had them copied, from the first 1703 article. Baker also reproduced the 1703 illustrations and some of the text in his 1742 book, with attribution to Anon. (1703a) as "Philosophical Transaction number 284" (Baker, 1742, plate VII) as did Adams (1756), who apparently copied Baker's text, illustrations and his attribution, but the illustrations of both Baker and Adams are barely recognizable. Hill, unlike Baker, oddly enough did not include the interesting organism that was probably 
Euplotes (Fig. G) in the plate from the first communication, here as Fig. 1 above). Hill also misrepresented some forms. He gave the vorticellid, described as extended and contracted in 1703 (Fig. M) in the plate from the first communication (Anon., 1703a, here as Fig. 1 above), as two different species, Craspedia spp $1 \& 3$.

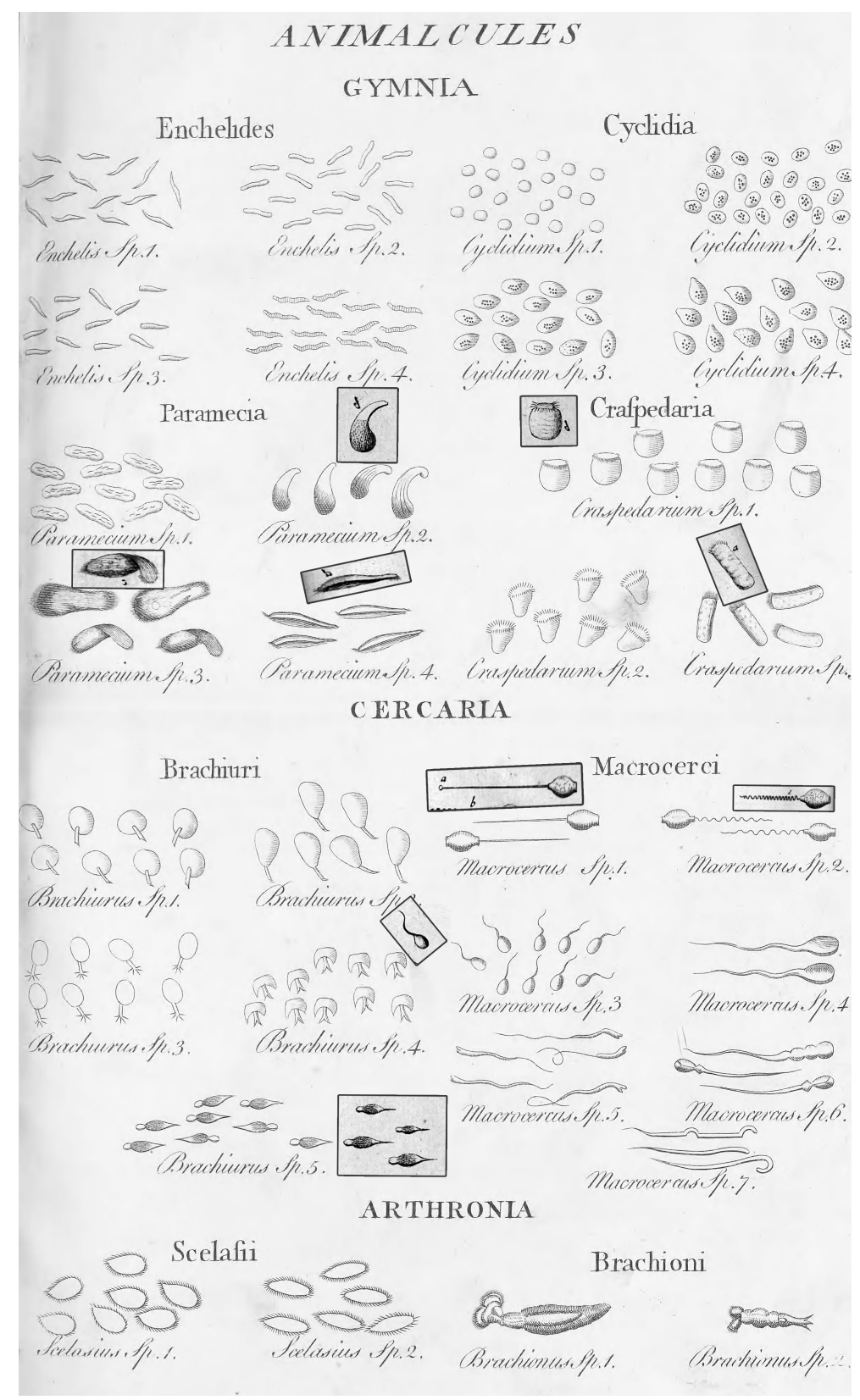

Figure 3. Plate 1 from John Hill (1752a). Inset images are from the plate accompanying Anon. 1703a. Note that the five insets in the upper half were inverted to conform to the orientations used in the 1752 plate (compare to Figure 1., above). 
With regard to the cell shown as Macroceras species 3, one of the copied illustrations, Hill does state that it is found in the semen of a stag, so he at least he did not misrepresent that finding of Charles King, he simply appropriated it. If indeed Hill did himself see all the forms shown of 'Macrocerci', by his text descriptions, he would have us believe that he examined the semen of a quite large variety of organisms ranging from "man and all the monkey tribe", to dogs, cats, hedgehogs, bats, moles, horses, toads, lizards, serpents, and "the drone bee and many other insects" (Hill, 1752a p. 9). In his book, Hill (1752a) apparently copied illustrations of other animals without attribution, for example the freshwater turtle (Bauer and Schaffer 2006).

Hill though was not the last person to copy the 1703 illustrations without giving any attribution. That particular dishonor appears to go to Thomas Dick (Dick, 1858) who used drawings and text in his book, "The Telescope and Microscope" (see page 127) without attribution from Adams (1746), taken from Baker (1742), both of the latter having cited 'Anon. 1703'.

Unlike Baker, Adams, and Dick, Hill did not copy the 1703 text. However, his text descriptions do suffer by comparison with those of Charles King. Below is Hill's text describing Paramecium species 3, the form nicely described in Anon. (1703a) as Figure F, the source of Hill's illustration (text given above).

"This is the number of the larger Animalcules. It is of an oblong figure; it's length is equal to about three times it's diameter, and it's colour a very pale brown, with a faint admixture of green. The head and tale are both obtuse, but they are smaller than the rest of the body: the skin is thin, smooth, and transparent, and the traces of the intestines are distinctly visible through it. It is tolerably swift in it's motions, and is able to twist and turn about it's body, and to double and fold it up in various manners, so as to appear of a very different shape from it's real one; and it has hence unluckily imposed upon many of the microscope observers, who have figured it as of different species under this diversity of appearances. It is not uncommon in ditch water; a third magnifer in the double microscope shews it very distinctly." (Hill, (1752a p. 4) 
Did John Hill possibly copy rather Henry Baker and not directly the anonymous contributor of 1703 ? Evidence that John Hill was quite familiar with articles published in the Philosophical Transactions in the early 1700's can be found in Hill's 1751 scathing review of the works of the Royal Society (Hill, 1751). Chapter 4 in Hill's book, on "A way to Catch Wild Ducks", ridicules a 1702 article by Stratchen "On the ways of catching fowl and deer, of serpents, of the ant bear and of cinamon" published in the second issue of volume 23, number 278 (Strachen, 1702). Hill, in reviewing Royal Society articles, certainly would have come across the letters from the anonymous contributor of 1703 , the first of which appeared in the ninth issue of the same volume, number 284 (Anon. 1703a).

Today, one might think that perhaps 'way back when' in the 1740's and 1750 's, plagiarizing might have been acceptable. However, there is good reason to believe that copying without attribution was considered unethical at the time. From the early 1700 's on, the term "pirate" commonly referred to a person who copied someone else's text (Johns, 2009). Among the early microscopists, copying was reviled as shown in the story of the reception of George Adams's Micrographia Illustrata. Henry Baker's 'The microscope made easy' first published in 1742 (that used the illustrations from Anon. 1703a with attribution) was a very successful book. For the first edition, 1000 copies were printed and sold in just five months (Jardine, 2016). By 1743, it reached the third edition. In 1746, George Adams, a maker and seller of microscopes, published a book, featuring lengthy advertisements for his microscopes, in which very large sections of both texts and illustrations were taken from Baker's book and Joblot's 1718 treatise (Joblot, 1718). Baker, outraged, tried to prevent sales of Adam's book on the grounds of plagiarism. He was mostly, but not entirely, unsuccessful as he did manage to have Adam's book banned from some dealers and his fellow members of the Royal Society were in large agreement with him that Adam's actions were unethical (Turner, 1974). Thus, it is difficult to condone Hill's appropriation of the 1703 illustrations as acceptable practice for the time. 
As a final note, investigating the early microscopists Henry Baker and John Hill, revealed another interesting relationship, distinct from any claims of copying. Oddly enough, both men were closely associated, albeit in very distinct manners, to the prominent literary figures Daniel Defoe, Jonathan Swift and Henry Fielding, generally acknowledged as the pioneers of the English novel (e.g., Neil, 1951). Henry Baker married the youngest daughter of Daniel Defoe, author of the first English novel, Robison Crusoe, and with Defoe, Baker founded a short-lived periodical (Turner, 1974). In his younger days Baker was a published poet and one of his poems was satirized by Jonathan Swift (author of Gulliver's Travels, etc.) to produce the now well-known ditty (Ford, 2001):

Great fleas have little fleas

Upon their backs to bite'em

The little fleas have lesser fleas

And so ad infinitum

John Hill's relationship with the third pioneer of the English novel, Henry Fielding (author of Tom Jones) was quite different. They conducted what is now known as "The Paper War of 1752-1753" in which Hill and Fielding savagely criticized the other's views of literary and political matters in dueling periodicals (Rousseau, 2012). These close relationships among scientific and literary figures emphasize a lack at that time of sharp divisions separating intellectual activities we now view as distinct. Perhaps John Hill was more a dramatist or journalist than a scientist and this in part explains his behavior with regard to using the findings of Charles King.

\section{Conclusion}

Although the evidence is largely indirect, it supports the hypothesis that the anonymous writer of 1703 was Charles King. Unfortunately, there is scant hope that direct evidence may exist as there is little or no surviving records of the editorial practice of the Philosophical Transactions for the year 1703 or the years around 1703 (Fyfe et al., 2017). One can only regret that that for centuries now Charles King has remained unknown as a fine, pioneer observer of protists and copepods. Meanwhile, all this time, a plagiarist, John Hill, has been credited with promoting and making attempts to classify protists, using the pilfered 
illustrations of Charles King. Lesser known or appreciated is that John Hill appears to have spent more time and energy in ridiculing other microscopists, especially those long deceased before him such as Leeuwenhoeck (as shown above) and Joblot (in Hill, 1752b, Essay VI), than in making any original observations on microorganisms. I hope then this present effort may help to rectify the history of protistology by not only revealing the talented Charles King but also bringing John Hill down a peg or two.

\section{Acknowledgements}

John Smol put me in contact with Patrick Kociolek and Luc Ector who pointed me towards some key references. David Montagnes, Marc Ratcliff, Lucy Ridler and Cailin Deery also provided aid in obtaining references. David Mann and Bernard Lightman provided valuable comments on an early version of this work. The remarks of anonymous reviewers and handling editor were invaluable in revising the paper. However, I retain full responsibility for all errors of fact and interpretation.

\section{References}

Adams G (1756) Micrographia Illustrata: or the microscope explained, in several new inventions, particularly of a new variable microscope for examining all sorts of minute objects; and also of a new camera obscura microscope designed fro drawing all minute objects, either by the light of the sun, or by lamp in winter evenings, to great perfection with a description of all the other microscopes now in use. Likewise a natural history of aerial, terrestrial, and aquatic animals, etc. considered as microscopic objects. 2 Ed., Printed for the Author, London, $325 \mathrm{p}$

Aescht E (2001) Catalogue of the generic names of ciliates (Protozoa, Ciliophora). Denesia, 1:1-350.

Anon. (1703a). An Extract of some Letters sent to Sir. C. H. relating to some Microscopical Observations. Communicated by Sir C.H. to the Publisher. Phil Trans, 23, No. 284:1357-1372 
Anon. (1703b). Two Letters from a Gentleman in the Country, relating to Mr. Leuwenhoeck's Letter in Transaction, No. 283. Communicated by Mr. C. Phil Trans, 23, No. 288:1494-1501

Baker H (1742) The Microscope Made Easy: or, I. The Nature, Uses, and Magnifying Powers of the Best Kinds of Microscopes Described, Calculated and Explained for the Instruction of Such, Particularly, as Desire to Search Into the Wonders of the Minute Creation, tho' they are not Acquainted with Optics, Together with Full Directions how to Prepare, Apply, Examine, and Preserve all Sorts of Objects, and Proper Cautions to be Observed in Viewing them. II. An Account of what Surprising Discoveries have been Already Made by the Microscope, with Useful Reflections on them: and also a Great Variety of New Experiments and Observations, Pointing out Many in Common Subjects for the Examination of the Curious. R. Dodsley, Tully's Head, Pall-Mall, $311 \mathrm{p}$

Bauer AM, Schaffer C (2006). The first published illustration of a pleurodon turtle? Biblio Herpetol, 6:4-10

Bruguière JG (1791) L'helminthologie ou les vers infusoires, les vers intestins, les versmolluques, etc. In Tableau Encyclopédique et Méthodique des Trois Règnes de la Nature, Livraison 7, Panchoucke, Paris, 180 p

Chatters C (2017) Saltmarsh. Bloomsbury, London, 384 p

Cole FJ (1926) The History of Protozoology. University of London Press, London, $64 \mathrm{p}$

Corliss JO (1978) A salute to fifty-four great microscopists of the past: a pictorial footnote to the history of protozoology. Part I. Trans Amer Microsc Soc, 97:419-458

Damkaer DM (2002) The Copepodologist's Cabinet: A Biographical and Bibliographical History. American Philosophical Society, Philadelphia, 297 p 
De Wolf H (1993) History of diatom research in The Netherlands and Flanders. Hydrobiologia, 269/270:1-9

Dick T (1858) The telescope and microscope. Lane \& Scott, New York, 178 p

Dobell C (1932) Antony van Leeuwenhoek and his "little animals" being some account of the father of protozoology and bacteriology and his multifarious discoveries in these disciplines. Harcourt, Brace \& Co., New York, 435 p

Dujardin F (1841) Histoire Naturelle des Zoophytes. Infusoires, comprenant la Physiolgie et la Classification de ces Animaux et La Maniere des les Etudier à l'Aide du Microscope. Librarie Encyclopédique de Roret, Paris, 683 p

Fokin SI (2004) A brief history of ciliate studies (late XVII - the first third of the XX century). Protistology, 3:283-296

Greenslade M (2008) Chetwynd, Walter (1633-1693), county historian. Oxford Dictionary of National Biography, https://doi.org/10.1093/ref:odnb/5250

Fyfe A, Moxham N, McDougall-Waters j, Mørk Røstvik (2017) Key facts datasheet for Philosophical Transactions in 1703, Publishing the Philosophical Transactions, 1665-2015. https://arts.st-andrews.ac.uk/philosophicaltransactions/keyfacts/1703

Hill J (1751) A review of the Works of the Royal Society of London; Containing Animadversions on Such of the Papers as Deserve Particular Observation. R. Griffiths, London, 265 p

Hill J (1752a) An History of Animals: Containing Descriptions of the Birds, Beasts, Fishes, and Insects, of the Several Parts of the World, and Including Accounts of the Several Classes of Animalcules, Visible Only by the Assistance of Microscopes. Thomas Osborne, London, $588 \mathrm{p}$ 
Hill J (1752b) Essays in Natural History and Philosophy Containing a Series of Discoveries by the Assistance of Microscopes. Whiston and White, London, $415 \mathrm{p}$

Jardine B (2016) Micoscopes. in Lightman B (ed) A Companion to the History of Science. John Wiley \&Sons Ltd, West Sussex, pp 515-529

Joblot L (1718) Descriptions et usages de plusieurs nouveaux microscopes, tant simples que composez, Collombat, Paris

Johns A (2009) Piracy: the intellectual property wars from Gutenburg to Gates. University of Chicago Press, Chicago, $626 \mathrm{p}$

King C (1701) A letter from Mr Charles King to Mr. Sam. Doudy, F.R.S. concerning Crabs Eyes. Phil Trans Roy Soc Lond, 22, No. 266:672-673

Kudo RR (1954) Protozoology, C.C. Thomas, Springfield, Ill. 966 p

Lahr DJ, Lara E, Mitchell EA (2012). Time to regulate microbial eukaryote nomenclature. Biol J Linn Soc, 107: 469-476

Leeuwenhoeck A van (1703) Part of a letter from Mr Antony van Leeuwenhoek, F.R.S. concerning green Weeds growing in Water, and some Animalcules found about them. Phil Trans Roy Soc Lond, 23, No. 283:13041311.

Mann DG (2002) Diatoms: organism and image. in du Buf H, Bayer, MM (eds) Automatic Diatom Identification, World Scientific Publishing, Singapore, pp 9-41.

Mann DG (2010) Discovering diatom species: is a long history of disagreements about species-level taxonomy now at an end? Pl Ecol Evol, 143:251-264 
Manton I (1983) Some neglected microscopical landmarks (1702-1820). Proc Roy Soc Micros (now called InFocus), 18:157-163.

Müller OF (1776) Zoologia Danicae Prodromius, seu Animalium Daniae et Norvegiae Indigenarum Characteres, Nomina, et synonyma imprimus popularium. Havniae, Typis Hallageriis. $282 \mathrm{p}$

Neill SD (1952) A short history of the English novel. Jarrolds, London, 340 p

Plot R (1686) The Natural History of Stafford-Shire. Theater, Oxford p 450

Ratcliff MR (2009) The quest for the invisible: microscopy in the enlightenment. Ashgate Publishing, Farnham, UK, 332 p

Round FE, Crawford RM, Mann DG (1990) The Diatoms Biology and Morphology of the Genera. Cambridge University Press, Cambridge, 747 p

Rousseau G (2012). The Notorious Sir John Hill The Man destroyed by Ambition in the Era of Celebrity. Lehigh University Press, Bethlehem, PA, USA, $389 \mathrm{p}$

S (1887) Quaeritur: Who was Mr. Charles King? Nature, 37:152.

Saville Kent W (1880-1881) A Manual of the Infusoria: Including a Description of All Known Flagellate, Ciliate, and Tentaculiferous Protozoa, British and Foreign and an Account of the Organization and Affinities of the Sponges. David Brogue, London, $913 \mathrm{p}$

Strachan M (1702). Observations Made in the Island of Ceilan, by Mr Strachan on the Ways of Catching Fowl and Deer, of Serpents, of the Ant Bear and of Cinamon. Phil Trans, 23, No. 278:1094-1096. 
Turner AJ (2004) Plot, Robert (bap.1640, d. 1696), naturalist and antiquary. Oxford Dictionary of National Biography, https://doi.org/10.1093/ref:odnb/22385

Turner GL'E (1974). Henry Baker, F.R.S.: Founder of the Bakerian Lecture. Notes Rec Roy Soc Lond, 29:53-79.

Wedgwood JC (1920) Staffordshire parliamentary history from the earliest times to the present day. Vol II, Part 1 (1603 to 1715). Collections for a History of Staffordshire, Vol 1920: 1-312.

Woodruff LL (1926) The versatile Sir John Hill. Amer Nat, 60:416-442 